\title{
How Do Corporate Social Responsibility Activities Influence Corporate Reputation? Evidence From Korean Firms
}

\author{
Kayondo Denis Mukasa, Makerere University Business School, Uganda \\ Kyungho Kim, Ajou University, South Korea \\ Hyunwoo Lim, Ajou University, South Korea
}

\begin{abstract}
This study applies the stakeholder theory and explores how corporate social responsibility (CSR) activities are associated with corporate reputation. In particular, we investigate how charitable contributions and toxic emissions as proxies for CSR activities are related with shareholder returns as a proxy for corporate reputation. This study employs a sample of Korean firms reported in the Korea sustainability index database between 2010 and 2012. The results find that charitable contributions and toxic emissions are positively and negatively related with shareholder returns, respectively. In addition, the results show that current shareholder returns are likely to be influenced by past charitable contributions and toxic emissions, suggesting that firms may develop current reputational competences by leveraging on past CSR activities.
\end{abstract}

Keywords: Corporate Social Responsibility; Corporate Reputation; Charitable Contributions; Toxic Releases; Shareholder Returns

\section{INTRODUCTION}

orporations are contributing to society through an economic profit, but at the same time they often cause society to suffer greatly due to unethical actions such as toxic emissions and deforestation. As corporations cannot earn profits unethically and irresponsibly, corporate social responsibility (CSR) has often been incorporated into a part of corporate primary strategy to pursue both sustainable and economic growth (Elkington, 1994; McWilliams \& Siegel, 2001; Orlitzky, Schmidt, \& Rynes, 2003; Post, 1978; Post, Preston, \& Sauter-Sachs, 2002).

As CSR has become a corporate fundamental issue to establish good corporate reputation over time, corporations have assigned considerable resources in managing diverse stakeholders such as local communities, poor neighbor countries, and the natural environment. The stakeholder perspective claims that CSR activities are likely to result in better corporate reputation and thus firms should not only consider the shareholders' interests but also all stakeholders' (Freeman, 1984). That is, corporate reputation can be improved by implementing stakeholders' CSR activities such as environmental (e.g., reducing toxic releases to the natural environment) and social (e.g., charitable contributions) initiatives. Corporate reputation can be corporate assets as corporations (i.e., shareholders) strengthen the relationships with diverse stakeholders including customers, investors, government, suppliers, and employees (Fombrun, 1996).

Fundamental issues often called for empirical research is how and whether CSR activities are related with corporate reputation (Fombrun, 1996). To answer the first question of 'how', this study attempts to link CSR activities and corporate reputation by employing both charitable contributions and toxic emissions as proxies for CSR activities and shareholder returns as a proxy for corporate reputation. 
In terms of the second issue of whether, one perspective argues that CSR and corporate reputation are positively related (Brammer \& Millington, 2004; Balmer \& Greyser, 2003) as CSR activities such as charitable contributions and environment-friendly practices enable firms to offset business shocks that could result from past irresponsible actions. The other perspective contends that CSR activities are not related with corporate reputation (Bartley, 2007; Klein, 2000; Seidman, 2007). This is premised on the argument that corporate credibility may not be enhanced if the CSR initiatives are primarily drafted with a profit generating motive. According to Walter (2012), CSR activities may tarnish the firm's image on the side of employees because some corporations increase the CSR budget while cutting employees' wages. Thus, our study carefully explores whether CSR activities are linked to corporate reputation, given these contrasting arguments. That is, our study sets out to provide statistical empirical evidence for the relationship.

Furthermore, corporations in developed countries have appreciated the impact of CSR on corporate reputation and attempted to incorporate it in all spheres of firm strategy (Ali, Rehman, Ali, Yousaf, \& Zia, 2010). Similarly, the CSR-reputation linkage also becomes a timely issue in developing countries. For instance, the Korean Federation of Environmental Movement and People's Solidarity for Participatory Democracy have been involved in CSR monitoring, evaluation of sustainability reports, pursuing CSR related lawsuits and lobbying the Korean government to make CSR reporting mandatory (Liem, 2011). Notwithstanding the emerging issue in Korea, little statistical evidence has been reported. Thus, this study specifically investigates the relationship between CSR activities of Korean large firms and their reputation.

In summary, although the literature about CSR emphasizes the close connection between shareholders' returns and stakeholders' CSR activities, it has little provided empirical evidence for the connection between them. In the following sections, we review the existing studies about the relationship between CSR activities and corporate reputation, introduce hypotheses, explain methods and sample, report and discuss the findings, and provide theoretical and practical implications. In the last section, we address concluding remarks and directions for future research.

\section{LITERATURE REVIEW}

\section{Corporate Social Responsibility}

The stakeholder theory claims that a corporation should not only consider the shareholders' interests but also all stakeholders' (Freeman, 1984). A stakeholder is defined as "any group or individual who can affect or is affected by the achievement of the organization's objectives" (Freeman, 1984: 46). Primary stakeholders include shareholders, investors, customers, employees, natural environment, NGO groups, and any other groups whose absence in core activities of the firm could lead to its collapse. The success of any corporation lies in the extent to which it is capable of dealing with the relationship with its stakeholders (Van Beurden \& Gossling, 2008).

The World Business Council for Sustainable Development (2000) defines CSR as the commitment by corporations to behave ethically and contribute to economic development while improving the quality of life of the workforce and the community at large. The literature often explores CSR in detail and establishes corporate social performance (CSP) related benefits or costs. One perspective, a relatively early perspective, emphasizes the classical economic grounds and postulates that "there is only one social responsibility of business; and that is to utilize resources and engage in activities aimed at increasing profits" (Friedman, 1970: 230). He argues that unless a clear mandate is given by the firm owners, CSR activities that do not improve company profits should not be financed. Davies (1973) points out that management often focuses on finance and operations and may be short of the requisite expertise to generate socially appealing decisions. Involvement in CSR would lead the firm into areas that are unrelated to their main goal (Hayek, 1969).

In contrast, the fact that resources are budgeted for CSR implies that CSR cannot be overlooked on economic grounds (Margolis, Elfenbein, \& Walsh, 2007). In addition, companies galvanize resources from the community (e.g., customers and local communities) and ideally they have a moral obligation as ethical citizens to give back to society. Corporations can capitalize on CSR to strengthen their competitive edge over rivals. For instance, McWilliams and Siegel (2001) state that companies with a profit maximizing objective can leverage on 
corporate social programs to create strategic advantages in the eyes of customers. Organizational efforts in CSR are thus referred to as rare, valuable, and non-substitutable like any other scarce resource as the resource based view (RBV) contends (McWilliams, Siegel, \& Wright, 2006). This view is premised on the argument that firms get involved in socially and environmentally responsible actions in order to ensure longevity in business and remain appealing in the eyes of the stakeholders (Carroll \& Shabana, 2010).

In addition, proactive CSR activities such as charitable contributions and reduction of toxic emissions are better than reactive ones such as complying with regulations when the firm is dealing with stakeholders (Hart \& Ahuja, 1996; Sharma, 2000; Sharma \& Henriques, 2005). That is, companies pursuing a proactive agenda support and engage in CSR activities prior to any negative information being received by customers (Carroll \& Bucholtz, 2009; Du, Bhattacharya, \& Sen, 2007), whereas reactive CSR entails engaging in CSR to protect the firm image or mitigate further harm to the firm after an unethical action has been disclosed to the public (Murray \& Vogel, 1997). Firms are usually in a better position to get access to resources when they get involved in CSR activities ahead of time, a position which is practical and saves firm resources that would be diverted to addressing social problems when they occur. Bernstein (2000) argues that corporations should be involved in proactive CSR activities, given the fact that the stakeholders strongly support these proactive firms.

\section{Corporate Reputation}

Corporate reputation relates to perceptual representation of an organization's present, past and future prospects that define the organization's general appeal to stakeholders (Fombrun, 1996), and it relates to the stakeholders' collective knowledge about and regards for a company in its organizational field (Rindova \& Petkova, 2005). Corporate reputation is something intangible that attracts various stakeholders to a firm (Fombrun \& Van Riel, 2004) and is likely to impact people's actions (Balmer, 2001).

Corporate reputation is one of the important aspects that move along with CSR activities (Fombrun \& Shanley, 1990). Customers, suppliers and the community in general usually want to associate themselves with firms with a good track record of CSR. Organizational citizenship results from high levels of motivation and commitment to tasks and stakeholder concerns (McGuire, Sundren, \& Schneeweis, 1988). Hence the aggregate effects could be based on corporate social performance by CSR activities which in turn result in good reputation.

In linking CSR activities to corporate reputation, one realizes that firms enhance their brand and corporate image (Bramer \& Pavelin, 2006; Rowley \& Berman, 2000), which are crucial components of corporate reputation. In addition to a good brand name for the company, supporting social causes together with ethical business practices may impact stakeholders' perception about the company which is one of the foundations of reputation (Fombrun \& Shanley, 1990). Corporate reputation depends on the company's success in addressing stakeholder demands as well as meeting their expectations. Therefore, CSR, as stated by Donaldson and Preston (1995), is fundamental in augmenting the firm's reputation. Bramer and Pavelin (2006), for example, point out that positive reputation results in continued participation of stakeholders in CSR activities. This is fundamental to the long term survival and profitability of the firm (Clarkson, 1995). Brammer and Millington (2005) refer to CSR as component of reputation that establishes trust and goodwill among stakeholders.

\section{HYPOTHESES}

\section{Toxic Emissions And Corporate Reputation}

A fundamental CSR element in the assessment of a firm's attractiveness is its environmental activities that include strategies to reduce toxic emissions (Tsoutsoura, 2004). Konar and Cohen (1997) argue that society often views companies with high levels of toxic emissions as bad corporate citizens. This subjects the firms to pressure from the community to lessen toxic emissions. Klassen and McLaughlin (1996) contend that large toxic emitters are more likely to have negative reputation unless they reduce toxic releases. It should be also noted that firms with high absolute toxic emissions are subject to negative attention from the media and civil society groups (Konar \& Cohen, 1997). This propels companies into drafting CSR strategies focusing on reduction of toxic emissions in order to improve their reputation. The increasing demand of stakeholders' interests in environmental performance continues 
to put pressure on firms to undertake environmental responsibility in their operations in order to satisfy the demands, gain public support, and improve corporate reputation (Oeyono, Samy, \& Bampton, 2001).

A good corporate policy on environmental sustainability has a notable influence on firm attractiveness in the eyes of stakeholders (Backhaus, Stone, \& Heiner, 2002). In the same vein, Greening and Turban (2000) highlight a view that prospective employees often pursue and prefer jobs in environmentally responsible corporations. Notably, a corporate track record in environmental practices and performance influences investors' confidence in the firm's prospects going by the perception associated with intangibles. Therefore, a firm with high levels of absolute emissions is likely to receive negative criticism from communities and this will scare away potential investors and customers. Environment-friendly actions like reduction in greenhouse gas emissions could be used as a strategic means by firms to respond to several stakeholder demands, whereas heavy toxic emissions are likely to hurt the firm reputation and performance. For example, the 2010 British Petroleum (BP) rig explosion and its weighty air pollution consequences on pollution resulted in around $\$ 10$ billion fines in August 2010 because Texas environmental regulators reported that the company had illegally emitted about 538,000 pounds of toxic chemicals during the explosion, in turn tarnishing BP's legitimacy and good reputation as an environment-friendly corporation.

Corporate initiatives geared towards environmental protection are not only socially responsible but also benefit firm performance through an improved corporate image (Salama, 2003). Similarly, environmentally appealing actions such as reduced emissions could improve the company's general image, thereby attracting more customers (McGuire et al., 1988). This implies that a company is likely to boost its reputation by adopting environment-friendly activities or implementing costly environmental practices that may also be a unique strategy to break into market segments that are environmentally conscious (Tsoutsoura, 2004).

To investigate whether CSR activities are related with corporate reputation, our study focuses particularly on the emotional appeal of shareholders (e.g., good feeling about the company, admiring, respecting and trusting the company). Black and Carnes (2000) argue that shareholder returns is one of the fundamental reputation drivers, qualifying shareholder returns as a corporate reputation proxy given the benefits that accrue to the firm once it attains trust from investors. We use shareholder returns as a proxy for estimating how appealing the shareholders find the company (Gardberg \& Hartwick, 1990). Given the argument above that the shareholder returns is likely to be affected by environmental performance, the following Hypothesis 1 can be assumed:

Hypothesis 1: Toxic emissions, ceteris paribus, are negatively related to shareholder returns

\section{Charitable contributions and corporate reputation}

Charitable contributions as CSR activity enhance corporate reputation among stakeholders and also lessen concerns relating to corporate misconduct (Navarro, 1988). Stakeholders often conduct an evaluation of a firm's charitable initiatives which come with a positive bearing on corporate reputation. Ricks (2000) argues that philanthropy in the name of corporate contributions needs to be strategically aligned with the firm's core competencies for the benefit of the community as well as to generate financial returns for the firm. Corporate philanthropy is likely to be one of the most cost-effective means for a corporation to widen its competitive context (Porter \& Kramer, 2002).

Investing in charity results in positive corporate reputation and builds goodwill with employees, customers and key regulatory institutions (Lev, Petrovits, \& Radhakrishnan, 2010). In the study conducted on eBay sellers, Elfenbein and McManus (2010) found that consumers prefer products that are tied to charity, suggesting that linking products on sale to charitable contributions results in more financial benefits such as shareholder returns. Wartick and Cochran (1985) argue that the rate of charitable donations has a positive association with corporate reputation. In addition, reputation links corporate contribution to shareholders' wealth by serving as a form of moral capital (Godfrey, 2005; Wartick \& Cochran, 1985). This moral capital is generated when stakeholders can positively assess organizational actions. Williams and Barrett (2000) found that the relationship between charitable contribution and corporate reputation is more significant for firms violating rules and regulations related to health and environment. 
That is, charitable contributions could be a springboard to improve corporate reputation (i.e., shareholder returns) tarnished by unlawful actions (Wang et al., 2008). Therefore, we can assume Hypothesis 2:

Hypothesis 2: Charitable contributions, ceteris paribus, are positively related to shareholder returns

\section{METHOD AND ANALYSIS}

\section{Sample Data}

Since 2002, Korean Standards Association (KSA) has recorded sustainability report of the large public companies, the Korea Sustainability Index (KSI). KSA has reported the sustainability since 2002, but it was recent years to have a considerable number of firms on the list. This study focuses on the firms operating in the major industry sectors between 2010 and 2012 during which a noticeable number of firms started reporting their sustainability performance to the KSA, given that only some firms were irregularly registered in the earlier years. For example, only two firms were included in 2003, 5 firms in 2004, and around 10 firms until 2007. Most of the firms are in chemical, steel, and other manufacturing sectors which are known for waste disposal, recycling and release of toxic emissions. This has aroused the need for CSR monitoring in Korea (Liem, 2011). During the observation period, we observed almost 80 firms, but the final sample includes only 60 companies because some dropped due to insufficient information for this study, in turn resulting in 180 firms by year cases.

This study also employs secondary public data including journal articles published by the Corporate Reputation Review, UN Global compact, and Global reporting Initiative (GRI). Publications of sampled companies and authoritative bodies such as the Reputation Institute were also reviewed. Particular emphasis is placed on environmental activities undertaken by these corporations dating the observation period.

\section{Dependent Variable}

This study employed shareholder returns, a proxy for corporate reputation as described earlier, as a dependent variable which measures the value of a firm in terms of stocks and shares over time (Porter \& Kramer, 2011) and emphasizes the emotional appeal of shareholders (Gardberg \& Hartwick, 1990). As Black and Carnes (2000) argue, shareholder returns well represent the fundamental reputation drivers. Shareholder returns combine share price appreciation and dividends paid to show the total return to the shareholder (i.e., shareholder returns $=$ change in stock price + dividends paidbeginning stock price). Given that our sample includes firms in different industry sectors, we log transformed shareholder returns of a firm in a given year to standardize corporate shareholder returns and control outliers.

\section{Independent Variables}

This study employs two proxies for CSR activities. First, we use charitable contributions including cash donations made for philanthropic causes (Brammer \& Millington, 2004; Brown, Helland, \& Smith, 2006; Griffin \& Mahon, 1997). We use log-transformed charitable contributions of a corporation in a given year to control outliers. Another proxy is measured by environmental performance which represents corporate efforts put on environmental protection (Margolis et al., 2007). This study employs total toxic emissions by a firm into the natural environment in a given year (Chatterji, Levine, \& Toffel, 2009; Hart \& Ahuja, 1996). We log transformed total toxic emissions to control the influence of outliers.

\section{Control Variables}

This study controls for return on assets (ROA), debt ratio, sales and net profit which may be correlated with shareholder returns. ROA measures corporate operating performance (Jensen, 1986) and is calculated by dividing a firm's net income by its total assets. Secondly, we control for debt ratio which measures the extent of the firm's leverage and is calculated as a firm's total debt divided by total assets. Thirdly, the study controls for sales because sales have been explicitly linked to corporate social responsibility (Baron, 2001). That is, firms with large sales are 
more likely to compete for socially responsible customers. We use log transformed sales to control for outliers. Our last control variable is net profit (Flammer, 2013) and we log transformed net profits to control for outliers.

\section{Analytic Method}

This study used ordinary least squares (OLS) regression with STATA analytic program to test the main hypotheses, given that the sample consists of panel data for three years. To identify the relationship between the variables in question, the following OLS equation is specifically used;

\section{$\mathrm{SR}=\mathrm{F}\left(\beta_{1} \mathrm{TE}+\beta_{2} \mathrm{CC}+\right.$ Control variables $\left.+\varepsilon\right)$}

Where, shareholder returns $(\mathrm{SR})=\log$ transformed shareholder returns of a firm in a given year; toxic emissions $(\mathrm{TE})=\log$ transformed toxic emissions of a firm in a given year; charitable contributions $(\mathrm{CC})=\log$ transformed charitable contributions made by a firm in a particular year; control variables

\section{RESULTS}

Table 1 is a summary of basic statistics such as means, standard deviations, and the minimum and maximum values of each variable.

Table 1: Basic Statistics

\begin{tabular}{lccccc}
\hline \multicolumn{1}{c}{ Variables } & Observations & Mean & Std. Dev. & Min & Max \\
\hline Sales (unit: 1,000 KWN) & 180 & 52576.92 & 70848.08 & 1334 & 414647 \\
Net profit (unit: $1,000 \mathrm{KWN})$ & 180 & 32505.39 & 63309.08 & 226 & 550651 \\
ROA & 180 & .0629444 & .0983591 & 0 & .93 \\
$\begin{array}{l}\text { Debt ratio } \\
\text { Toxic emissions (unit: ton) }\end{array}$ & 180 & .8997778 & .7446554 & .1 & 4.68 \\
$\begin{array}{l}\text { Charitable contributions } \\
\text { (unit: } 1,000 \text { KWN) }\end{array}$ & 180 & 75444.32 & 144427.5 & 380 & 731801 \\
$\begin{array}{l}\text { Shareholder returns } \\
\text { (unit: } 1,000 \mathrm{KWN} \text { ) }\end{array}$ & 180 & 14345.64 & 25183.04 & 58 & 160582 \\
& & 22530.11 & 62874.33 & 100 & 480105 \\
\hline
\end{tabular}

A correlation matrix in Table 2 shows the expected correlations between variables in question. As we expected, the results show that charitable contributions and shareholder returns are positively correlated $(\mathrm{r}=0.427)$ and that toxic emissions are negatively correlated with shareholder returns $(\mathrm{r}=-.083)$ at a significance level $(\mathrm{p}<$ $.05)$. Hence, the results suggest that corporate socially responsible activities are highly correlated with corporate reputation (Bronn \& Vrion, 2001).

Table 2: Correlation Matrix, $\quad * p<0.05$

\begin{tabular}{lcccccc}
\hline & Sales & Net Profit & ROA & Debt Ratio & $\begin{array}{c}\text { Toxic } \\
\text { Emissions }\end{array}$ & $\begin{array}{c}\text { Charitable } \\
\text { Contributions }\end{array}$ \\
\hline Sales & 1 & & & & & \\
Net profit & -0.0066 & 1 & & & & \\
ROA & -0.0081 & 0.0201 & 1 & & & \\
Debt ratio & -0.0200 & 0.0179 & -0.099 & 1 & & \\
Toxic emissions & $0.1788^{*}$ & 0.0748 & 0.0780 & 0.1181 & 1 & 1 \\
Charitable contribution & -0.0985 & 0.0197 & -0.060 & 0.0472 & -0.0690 & 1 \\
Shareholder returns & -0.0561 & 0.0561 & -0.047 & 0.0011 & $-0.0832^{* *}$ & $0.427^{*}$ \\
\hline
\end{tabular}

We carried out multicollinearity test with help of the variance inflation factor (VIF) which is commonly recommended as post estimation check (Kleinbaum, Kupper, Muller, \& Nizam, 1998). The results show that there is no multicollinearity problem. The study controls for some confounding effects. The results in Model 1 of Table 3 do not show any statistical significance for the control variables, suggesting that any control variables do not matter much in explaining corporate reputation. For example, the results present that sales have an insignificant effect on 
corporate reputation, suggesting that a firm may improve sales without an impact on its reputation. The results in Model 1 imply that the primary variables are more considerable in explaining corporate reputation.

We conducted a number of nested regressions to carefully explore how corporate reputation is influenced by CSR activities. That is, we regressed shareholder returns on toxic emissions and charitable contributions through Models 1, 2, 3, and 4 while controlling for sales, debt ratio, ROA, and net profits.

The results show that toxic emissions have an expected negative relationship with shareholder returns across all models (except for Model 4, or 2-year lagged model) at a significant level, supporting Hypothesis 1 . The results in Table 3 also present that charitable contributions have a positive relationship with shareholder returns across all models at a significant level, strongly supporting Hypothesis 2 . The results in Models 1 and 2 provide statistical empirical evidence for the argument.

Table 3: Regression Analysis For Effect Of CSR Activities On Corporate Reputation

\begin{tabular}{|c|c|c|c|c|}
\hline & $\begin{array}{c}\text { Model 1 } \\
\text { Concurrent }\end{array}$ & $\begin{array}{c}\text { Model 2 } \\
\text { Concurrent }\end{array}$ & $\begin{array}{c}\text { Model 3 } \\
1 \text { year lagged }\end{array}$ & $\begin{array}{c}\text { Model } 4 \\
2 \text { years lagged }\end{array}$ \\
\hline Sales & $\begin{array}{c}2401.6 \\
(3568.32)\end{array}$ & $\begin{array}{l}.0046 \\
(.0647)\end{array}$ & $\begin{array}{c}1289.35 \\
(4144.47)\end{array}$ & $\begin{array}{c}2293.47 \\
(6308.34)\end{array}$ \\
\hline Debt ratio & $\begin{array}{l}-4609.85 \\
(6534.64)\end{array}$ & $\begin{array}{l}-6652.11 \\
(6317.59)\end{array}$ & $\begin{array}{l}-6439.23 \\
(7414.39)\end{array}$ & $\begin{array}{c}-7987.91 \\
(11741.51)\end{array}$ \\
\hline Net profit & $\begin{array}{l}-.0416 \\
(.0741)\end{array}$ & $\begin{array}{l}-.0578 \\
(.0715)\end{array}$ & $\begin{array}{l}-.0484 \\
(.0742)\end{array}$ & $\begin{array}{l}-.0406 \\
(.0965)\end{array}$ \\
\hline ROA & $\begin{array}{c}-20777.04 \\
(47959)\end{array}$ & $\begin{array}{c}-5447.53 \\
(46365.66)\end{array}$ & $\begin{array}{c}-674.63 \\
(47466.12)\end{array}$ & $\begin{array}{c}5833.70 \\
(76445.91)\end{array}$ \\
\hline Toxic emissions & $\begin{array}{c}-6529.44 * * \\
(2633.40)\end{array}$ & $\begin{array}{c}-6192.17 * * \\
(2550.80)\end{array}$ & $\begin{array}{l}-5466.76^{*} \\
(3011.17)\end{array}$ & $\begin{array}{l}-6438.37 \\
(4602.66)\end{array}$ \\
\hline Charitable Contributions & & $\begin{array}{c}10392.86 * * * \\
(2697.53)\end{array}$ & $\begin{array}{c}10965.89 * * * \\
(3206.81)\end{array}$ & $\begin{array}{c}12006.78^{* *} \\
(4939.01)\end{array}$ \\
\hline Observations & 180 & 180 & 120 & 60 \\
\hline R-square & 0.0383 & 0.1130 & 0.1250 & 0.1364 \\
\hline Adj. R-square & 0.0107 & 0.0875 & 0.0785 & 0.0386 \\
\hline
\end{tabular}

Note: $* * * \mathrm{P}<.01, * * \mathrm{P}<.05, * \mathrm{P}<.1$

In Models 3 and 4, we tested the lagged effects of primary variables, given that current social performance of a firm may be influenced by its past CSR activities, a so-called time lagged effect (Chatterji et al., 2009; Margolis et al., 2007) and that corporate reputation relates to perceptual representation of an organization's present, past and future prospects (Fombrun, 1996). The results in Model 3 show that one-year lagged toxic emissions and charitable contributions have an expected effect on current reputation at a strong significant level. In Model 4, it is only twoyear lagged charitable contributions with statistical significance to reflect a relationship with corporate reputation $(\mathrm{p}<.05)$. The results in Models 3 and 4 provide statistical evidence for the recent argument that current corporate social performance cannot be isolated from its own past CSR activities (Margolis et al., 2007).

\section{DISCUSSION AND IMPLICATIONS}

This study carefully explored how CSR activities affect corporate reputation to provide statistical empirical evidence for the recent inconsistent arguments: positive versus nonrelated relationship between corporate reputation and CSR activities. In specific, the study employed the sample of Korean public large companies in diverse heavy polluting industries between 2010 and 2012, and we tested the main hypotheses by using charitable contributions and toxic emissions as proxies for CSR activities and shareholder returns as a proxy for corporate reputation.

The results support Hypothesis 1 that toxic emissions are negatively related with shareholder returns, suggesting that worse environmental activities of a firm may hurt its reputation. In other words, doing worse to the natural environment may risk its reputation which in a long run affects social performance as well (Margolis et al., 2007), providing empirical evidence for the main argument of stakeholder theory (Freeman, 1984; 1998). The findings suggest that firms ought to be careful and deviate from any harmful actions that could endanger 
stakeholders such as the natural environment (Freeman, Wicks \& Palmar, 2004; Lantos, 2001). This is thus a call to Korean firms and beyond to accelerate or engage in CSR activities targeted towards reducing toxic emissions.

As predicted, the results supported Hypothesis 2 that assumes a positive relationship between charitable contributions and shareholder returns. That is, our findings proved that CSR activity through charitable contributions has a significant positive effect on better corporate reputation. This concurs with Barry (2000)'s view that charity driven CSR activity has a positive influence on reputation, although it may appear challenging for firms to invest in CSR through donations amidst a highly competitive economic environment. Findings in Model 2 also support the argument by Elfenbein and McManus (2010) that society associates itself more with goods tied to charity and also deems firms that contribute to charity as highly reputable. This suggests that firms involved in CSR activities through charitable contributions are likely to have a high reputation in the eyes of stakeholders (Brammer, Pavelin, \& Porter, 2009). These findings suggest that corporations should incorporate CSR activities into a main strategy arena to increase corporate value and sustainable growth.

The results in Model 2 also strengthen the view that proactive CSR activities such as charitable contributions or voluntary reduction of toxic emissions, offer a win-win situation to both the corporation and the society (Reinhardt, 1999; Nelson 1994; Esty \& Porter, 1998). In addition, Hamilton (1995) also theorized this view by stating that heavily emitting firms are bound to lose market valuation upon disclosure of toxic releases inventory information. Orlitzky et al. (2003) also found that firms that are environmentally careless with high volumes of toxic releases risk their reputation which in turn could as well influence corporate financial performance. Our findings provide statistical evidence for the argument that corporate environmental performance (i.e., less toxic emissions into the natural environment) offers a number of reputational benefits (Hart, 1997).

In Model 3, we conducted one year lagged effect of independent variables and two years lagged effect on current corporate reputation in Model 4. The results in Model 3 show that both one-year lagged toxic emissions and charitable contributions have a significant effect on current shareholder returns (i.e., current corporate reputation). The results in Model 4 show that only two-year lagged charitable contributions have a significant effect on current shareholder returns. These findings imply that current better corporate reputation is influenced by past corporate CSR activities. In addition, the results in the lagged models provide evidence for the argument of RBV (Barney, 1992) that companies can develop current competences and a pool of resources by leveraging on past experience.

The study provides several practical and theoretical implications to the field of strategic management and CSR literature. Previous studies yielded mixed results on how CSR activities affect corporate reputation. One stream of research argues a positive relationship (McGuire et al., 1988; Ullman, 1985; Wood, 1995), and the other stream contends that the relationship is not associated (Barley, 2007; Seidman, 2007). This study provides statistical evidence for the positive relationship: that is, more charitable contributions and smaller toxic emissions are likely to lead to the improved corporate reputation. The results suggest that proactive CSR activities in these two areas could enhance corporate value in terms of shareholder returns. This finding supports the argument of Podnar and Golob (2007) that involvement in charitable initiatives results in positive media coverage, thereby building a reputation of integrity, consumer preference and a highly motivated workforce.

This study set out to extend the stakeholder theory by linking CSR activities with corporate reputation. According to the results, society is drawn closer to firms that contribute to charity and commit efforts to reduce toxic emissions. The findings of this study amplify the stakeholder theory by asserting that corporations must be balanced in addressing the demands of multiple stakeholders (local community, employees, and suppliers) who directly or indirectly influence the firm's operations. We contend that corporations can benefit by engaging in CSR activities that are important to non-financial stakeholder groups such as communities and pro-environmental groups. This includes controlling the toxic emissions that affect society and the natural environment.

Regarding practical implications, first, firms have asked how to incorporate CSR activities into the purview of corporate core strategy and what are the subsequent consequences of CSR activities. This study suggests that firms need to allocate resources effectively to incorporate CSR activities such as charitable contributions or environmental sustainability activities into their main strategy arena, given that social performance in these two areas is closely related with corporate reputation which in turn results in better economic performance. Therefore, 
companies need to make CSR an integral component of their corporate strategic because it is increasingly becoming a means of strategic investment.

Secondly, regarding the principles of CSR (Wood, 1991), environmental performance is expected to be one of the core components in the measurement of corporate reputation. Additionally, the results suggested that environmental performance through reduced emissions could lead to a positive corporate image. Accordingly, firms should make conscious efforts to reduce the level of toxic emissions through technological innovations. This study implies that corporations get involved in effective and sustainable contributions to community with a view of enhancing corporate reputation (Bruch \& Walter, 2005; Porter \& Kramer, 2002). As Carroll and Bucholtz (2009) put it, there is a change in trend from mere philanthropy to strategic philanthropy as charitable contributions often aid in improving reputation and accomplishing the subsequent financial objectives.

Thirdly, as shown in lagged Models 3 and 4, current shareholder returns are greatly influenced by previous CSR activities. Thus, firms need to pay attention to developing current CSR capabilities and resources to create and sustain better corporate reputation in the future which in turn lead to better economic performance.

Lastly, the results reflect that CSR is instrumental in achieving corporate reputation. Therefore, firms should draft a proactive CSR agenda. This can cut down costs, mitigate harm and enhance operational efficiency. For instance, lowering toxic emissions can reduce the costs associated with environmental regulations. In addition, investors are increasingly considering CSR as akin to good corporate governance and risk management.

\section{LIMITATIONS AND FUTURE STUDY}

This study has some limitations. First, constraints in relation to time and resources seem to have limited the ability to conduct an in-depth study of all companies with CSR engagements in Korea. We limited our study to the KSI database because it was the only available data source. In addition to this, primary data would have supplemented secondary sources for better results but accessibility was an uphill task.

Secondly, regarding some proxies such as charitable contributions, the study solely concentrates on contributions reported in cash. It does not include donations in terms of services which are not quantifiable in monetary terms. For example, some Korean firms engage in community sensitization and healthy campaigns. However, some of these physical contributions are left out yet their impact in terms of finance and firm reputation could be immense.

Thirdly, this study is comprised of a small sample size, which is associated to some shortfalls of the KSI database. Some firms had missing data and were not included in the final data for analysis. In addition, some variables could not provide any statistically significant result.

Lastly, most studies often focus on public large firms. Given the firm size does matter most with increasing CSR activities for better corporate reputation, Future research could be focused on small and medium sized companies to extend the expected relationship between CSR activities and corporate reputation. This could provide better representation in a situation where limited economic resources may necessitate prioritization of areas of investment. Furthermore, future research could be narrowed down to a specific industry sector in order to investigate the impact of CSR in a smaller context as results from several sectors are at times mixed and ambiguous.

\section{CONCLUSION}

The findings show that corporate reputation can increase by reduced toxic emissions and increased charitable contributions. From the results, we can assume that the CSR-reputation link helps firms in a developed market context mitigate losses and use their reputable positions to gain competitive advantage. Therefore, CSR activities can be a fundamental part of any firm's corporate strategy. Corporations can turn societal and environmental risks into business opportunities through proactive CSR. 


\section{AUTHOR INFORMATION}

Kayondo Denis Mukasa is a lecturer at Makerere University Business School. He received his MS degree from Graduate School of International Studies, Ajou University. He is interested in international business strategy, corporate social responsibility, and business ethics. Email: dkayondomukasa@ gmail.com

Kyungho Kim is an assistant professor at School of Business, Ajou University. He received his DBA from Boston University. His research areas include corporate strategy, international business strategy, corporate social responsibility, and environmental sustainability. Kyungho Kim, School of Business, Ajou University, San 5, Woncheon-dong, Yeongtong-gu, Suwon, 443-749, South Korea. E-mail:kyunghokim@ajou.ac.kr

Hyunwoo Lim is an assistant professor at School of Business, Ajou University. He received his PhD in Management from University of Toronto. His research areas include marketing strategy, econometric modeling, and international marketing. Hyunwoo Lim, School of Business, Ajou University, San 5, Woncheon-dong, Yeongtonggu, Suwon, 443-749, South Korea. E-mail: hyunwoolim@ajou.ac.kr (Corresponding author)

\section{REFERENCES}

Ali, I., Rehman, K.U., Ali, S.I., Yousaf, J., \& Zia, M. (2010). Corporate social responsibility influences, employee commitment and organizational performance. African Journal of Business Management, 4(12), 2796-2801.

Backhaus, K., Stone, B.A., \& Heiner, K. (2002). Exploring the relationship between corporate social performance and employer attractiveness. Business and Society, 41(3), 292-318.

Balmer, J.M.T. \& Greyser, S.A. (2003). Revealing the corporation: Perspectives on identity, image, reputation, corporate branding, and corporate- level marketing. European Journal of Marketing, 37(7), 1142-1144.

Baron, D. (2001). Private politics, corporate social responsibility and integrated strategy. Journal of Economics and Management strategy, 10(1), 7-45.

Barney, J.B. (1992). Integrating organizational behavior and strategy formulation research: A resource based Analysis. Advances in strategic management, 8(1), 39-61.

Bartley, T. (2007). Institutional emergence in an era of globalization: The rise of transnational private regulation of labor and environmental conditions. American Journal of Sociology, 113(2), 297-351.

Barry, N.P. (2000). Controversy: Do Corporations have any responsibility beyond making a profit? Journal of Markets and Morality, 3(1), 100-107.

Bernstein, A. (2000). Too much corporate power. Business Week, $11^{\text {th }}$ September, 149.

Black, E.L., Carnes, T.A., \& Richardson, V.J. (2000). The market valuation of corporate reputation. Corporate Reputation Review, 31(1), 31-42.

Brammer, S.J. \& Pavelin S. (2006). Corporate reputation and social performance: The importance of fit. Journal of Management Studies, 43(3), 435-455.

Brammer, S. \& Millington, A. (2004). The development of corporate charitable contributions in the UK: A stakeholder analysis. Journal of Management studies, 41(8), 1411-1434.

Brammer, S.J., Pavelin, S., \& Porter, L.A. (2009). Corporate charitable giving, multinational companies and countries of concern. Journal of Management Studies, 46(4), 575-596.

Bronn, P.S. \& Vrioni, A.B. (2001). Corporate social responsibility and cause-related marketing: An overview. International Journal of Advertising, 20(2), 207-222.

Brown, W. O., Helland, E., \& Smith, J.K. (2006). Corporate philanthropic practices. Journal of Corporate Finance, 12(5), 855-877.

Bruch, H. \& Walter, F. (2005). The key to rethinking corporate philanthropy. MIT Sloan Management Review, 47(1), 49-55.

Carroll, A.B. \& Shabana, K. (2010). The Business case for CSR: Review of concepts, research and practice. International Journal of Management Review, 12(1), 85-105.

Carroll, A.B. \& Bucholtz, A.K. (2009). Business and society: Ethics and stakeholder management. Mason, O.H: South Western Cengage Learning.

Chatterji, A.K., Levine, D.I., \& Toffel, M.W. (2009). How well do social ratings actually measure corporate social responsibility? Journal of Economics and Management Strategy, 18(1), 125-169. 
Clarkson, M.E. (1995). A stakeholder framework for analyzing and evaluating corporate social performance. Academy of Management Review, 20(1), 92-117.

Davies, K. (1973). The case for and against business assumption of social responsibility. Academy of Management Journal, 16(2), 312-322.

Donaldson, T.L. \& Preston, L.E. (1995). The stakeholder theory of the corporation: concepts, evidence and implications. Academy of Management Review, 20(1), 65-91.

Du, S., Bhattacharya, C.B., \& Sen, S. (2007). Reaping relational rewards from corporate social responsibility: The role of competitive positioning. International Journal of Research in Marketing, 24(3), 224-241.

Elfenbein, D.W. \& McManus, B.(2010). A greater price for a greater good? Evidence that consumers pay more for charity-linked products. American Economic Journal: Economic Policy, 2(2), 28-60.

Elkington, J. (1994). Towards a sustainable corporation: Win-win business strategies for sustainable development. California Management Review, 36(2), 90-100.

Esty, D. \& M. Porter. (1998). Industrial ecology and competitiveness: Strategic implications for the firm. Journal of Industrial Ecology, 2(1): 35-43.

Fombrun, C.J. (1996). Reputation: Realizing value for corporate image, Harvard Business School Press, Boston, M.A

Fombrun, C.J. \& Shanley, M. (1990). What's in a name? Reputation building and corporate strategy. Academy of Management Journal, 33(2): 233-258.

Flammer, C. (2013). Does corporate social responsibility lead to superior financial performance? A regression discontinuity approach. MIT Working Paper.

Friedman, M. (1970). The social responsibility of business is to increase its profits. New York Times Magazine, New York.

Friedman, J. (2013). Milton Friedman was wrong about corporate social responsibility. The Huffington Post, June $12^{\text {th }}$,http://www.huffingtonpost.com/john-friedman/milton-friedman-was-wrong_b_3417866.html

Freeman, E. (1984). Strategic Management: A stakeholder Approach. Boston Pitman.

Freeman, R.E., Wicks, A.C., \& Palmer, B. (2004). Stakeholder theory revisited. Organizational Science, 15(3), 364-369.

Gardberg, M.E. \& Hartwick, J. (1990). The effects of advertiser reputation and extremity of advertising claims on advertising effectiveness. Journal of Consumer Research, 17(2), 172-179.

Godfrey, P.C. (2005). The Relationship between corporate philanthropy and shareholder wealth: A risk management perspective. Academy of Management Review, 30(4), 777-798.

Greening, D.W., \& Turban, D.B. (2000). Corporate social performance as a competitive advantage in attracting a quality workforce. Business and Society, 39(3), 254-303.

Griffin, J.J. \& Mahon, J.F. (1997). The corporate social performance and corporate financial performance debate: Twenty five years of incomparable research. Business and Society, 36(1), 5-31.

Hamilton, J. (1995). Pollution as news: Media and stock market reactions to the toxic release inventory data. Journal of Environmental Economics and Management, 28(1), 98-113.

Hart, S. \& G. Ahuja, (1996). Does it pay to be green? An empirical examination of emissions reduction and firm performance. Business Strategy and the Environment, 5, 30-37.

Hart, S. (1997). Beyond Greening: Strategies for a Sustainable World. Harvard Business Review, 75(1): 66-76.

Hayek, F.A. (1969). The Corporation in a democratic society: In whose interest ought it and will it be run? In Ansoff. H. (ed.), Business Strategy. Harmondsworth: Penguin Books.

Jensen, M.C. (1986). Agency costs of free cash flow, corporate finance, and takeovers. The American Economic Review, 76(2), 323-329.

Klein, N. (2000). No logo: Taking aim at the brand bullies. Vintage Cananda.

Kleinbaum, D.G., Kupper, L.L., Muller, K.E., \& Nizam, A. (1998). Applied regression analysis and other multivariable methods. Pacific Grove: Duxbury Press.

Konar, S. \& Cohen, M. A. (1997). Information as regulation: The effect of community right to know laws to toxic emissions. Journal of Environmental Economics and Management, 32(1), 109-124.

Lantos, G.P. (2001). The boundaries of strategic corporate social responsibility. Journal of Consumer Marketing, 18(7), 595-630.

Lev, B., Petrovits, C., \& Radhakrishnan, S. (2010). Is doing good good for you? How corporate charitable contributions enhance revenue growth. Strategic Management Journal, 31(2), 182-200.

Liem, W.S. (2011). Corporations, unions and corporate social responsibility in South Korea: The reality of 
corporate social responsibility. Asia Monitor Resource Center.

Margolis, J.D., Elfenbein, H.A., \& Walsh, J.P. (2007). Does it pay to be good? A meta-analysis and redirection of research on the relationship between corporate social and financial performance. Working Paper, Harvard Business School, Boston, MA.

McGuire, J.B., Sundren, A., \& Schneeweis, T. (1988). Corporate social responsibility and firm performance. Academy of Management Journal, 31(4), 854-872.

McWilliams, A. \& Siegel, D. (2001). Corporate social responsibility: A theory of the firm perspective. Academy of Management Review, 26(1), 117-127.

McWilliams, A., Siegel, D.S., \& Wright, P.M. (2006). Corporate social responsibility strategic implications. Journal of Management Studies, 43(1), 1-18.

Murray, K.B. \& Vogel, C.M. (1997). Using a hierarchy of effects approach to gauge the effectiveness of CSR to generate goodwill towards the firm: Financial versus nonfinancial impacts. Journal of Business Research, 38(2), 141-159.

Navarro, P. (1988). Why do corporations give to charity? Journal of Business, 61(1): 66-75.

Oeyono, J., Samy, M., \& Bampton, R. (2011). An examination of corporate social responsibility and financial performance. Journal of Global Responsibility, 2(1), 100-112.

Orlitzky, M., Schmidt, F.L., \& Rynes, S.L. (2003). Corporate social and financial performance: A meta-analysis. Organization Studies, 24(3), 403-41.

Podnar, K. \& Golob, U. (2007). CSR expectations: The focus of corporate marketing. Corporate Communications: An International Journal, 12(4), 326-340.

Porter, M.E. \& Kramer, M.R. (2011). The big idea: Creating shared value. Harvard Business Review, JanuaryFebruary: 1-7.

Porter, M.E. \& Kramer, M.R. (2002). The competitive advantage of corporate philanthropy. Harvard Business Review, December: 5-16.

Post, J.E. (1978). Corporate behavior and social change. Reston Pub.Co., Reston, VA.

Post, J.E., Preston, L.E., \& Sauter-Sachs, S. (2002). Redefining the corporation: Stakeholder management and organizational wealth. Stanford University Press, Stanford, CA.

Reinhardt, F. (1999). Market failure and the environmental policies of firms. Journal of Industrial Ecology, 3(1), 9-21.

Ricks Jr, J. M. (2005). An assessment of strategic corporate philanthropy on perceptions of brand equity variables. Journal of Consumer Marketing, 22(3), 121-134.

Rindova, V.P. \& Petkova, A.P. (2005). Entrepreneurial reputation. The Blackwell Encyclopedia of Management, Blackwell Publishing, Malden: MA.

Rowley, T. \& Berman, S. (2000). A brand new brand of corporate social performance. Business and Society, 39(4), 397-418.

Salama, A.I. (2003). A median regression analysis of the relationship between environmental reputation and corporate financial performance: Empirical evidence on UK firms. The Rensselaer Polytechnic Institute Conference, October, New York.

Schwaiger, M. (2004). Components and parameters of corporate reputation: An empirical study. Schmalenbach Business Review, 56(1), 46-71.

Seidman, Gay W. (2007). Beyond the boycott: Labor rights, human rights and transnational activism. New York: Russell Sage Foundation.

Sharma, S. (2000). Managerial interpretations and organizational context as predictors of corporate choice of environmental strategy, Academy of Management Journal, 43(4), 681-697.

Sharma, S. \& Henriques, I. (2005). Stakeholder influences on sustainability practices in the Canadian forest products industry, Strategic Management Journal, 26(2), 159-180.

Tsoutsoura, M. (2004). Corporate social responsibility and financial performance. Working Paper, Haas School of Business, University of California at Berkeley.

Ullmann, A.A. (1985). Data in search for a theory: A critical examination of the relationships among social performance, social disclosure and economic performance of US firms. Academy of Management Review, 10(3), 540-557.

Van Beurden, P. \& Gössling, T. (2008). The worth of value: A literature review on the relation between corporate social and financial performance. Journal of Business Ethics, 82(2), 407-424.

Walter, B.L. (2012). Does corporate social responsibility really contribute to reputation? In B. Baybars-Hawks 
\& O.Samast (eds.), New challenges, new opportunities: Interdisciplinary perspectives on reputation management (Reputation Management Institute), pp. 55-64.

Wang, H., Choi, J., \& Li, J. (2008). Too little or too much? Untangling the relationship between corporate philanthropy and firm financial performance. Organizational Science, 19(1), 143-159.

Wartick, S. \& Cochran, P. (1985). The Evolution of the corporate social performance model. Academy of Management Review, 10(4), 758-769.

Williams, R.J. \& Barrett, J.D. (2000). Corporate philanthropy, criminal activity and firm reputation: Is there a link? Journal of Business Ethics, 26(4), 341-350.

Wood, D.J. (1991). Corporate social performance revisited. Academy of Management Review, 16(4): 691-718.

World Business Council for sustainable development (2000), Corporate Social Responsibility: Meeting Changing expectations. 


\section{NOTES}

